ISSN 1996-1944

www.mdpi.com/journal/materials

Review

\title{
Review of the Potential of the Ni/Cu Plating Technique for Crystalline Silicon Solar Cells
}

\section{Atteq ur Rehman and Soo Hong Lee*}

Green Strategic Energy Research Institute, Department of Electronics Engineering, Sejong University, 98 Gunja-dong, Gwangjin-gu, Seoul 143-747, Korea; E-Mail: atteq@sju.ac.kr

* Author to whom correspondence should be addressed; E-Mail: shl@ sejong.ac.kr;

Tel.: +82-2-3408-3879; Fax: +82-2-3408-4157.

Received: 4 December 2013; in revised form: 21 January 2014 / Accepted: 10 February 2014 /

Published: 18 February 2014

\begin{abstract}
Developing a better method for the metallization of silicon solar cells is integral part of realizing superior efficiency. Currently, contact realization using screen printing is the leading technology in the silicon based photovoltaic industry, as it is simple and fast. However, the problem with metallization of this kind is that it has a lower aspect ratio and higher contact resistance, which limits solar cell efficiency. The mounting cost of silver pastes and decreasing silicon wafer thicknesses encourages silicon solar cell manufacturers to develop fresh metallization techniques involving a lower quantity of silver usage and not relying pressing process of screen printing. In recent times nickel/copper $(\mathrm{Ni} / \mathrm{Cu})$ based metal plating has emerged as a metallization method that may solve these issues. This paper offers a detailed review and understanding of a $\mathrm{Ni} / \mathrm{Cu}$ based plating technique for silicon solar cells. The formation of a $\mathrm{Ni}$ seed layer by adopting various deposition techniques and a $\mathrm{Cu}$ conducting layer using a light induced plating (LIP) process are appraised. Unlike screen-printed metallization, a step involving patterning is crucial for opening the masking layer. Consequently, experimental procedures involving patterning methods are also explicated. Lastly, the issues of adhesion, back ground plating, process complexity and reliability for industrial applications are also addressed.
\end{abstract}

Keywords: metallization; solar cell; efficiency; screen printing; photovoltaic; contact resistance; nickel/copper; metal plating; light induced plating (LIP); adhesion 


\section{Introduction}

Developing an improved method for the metallization of silicon solar cells is essential for realizing greater efficiency. Currently, contact formation using screen printing is the dominant technology in the silicon based photovoltaic industry, as it is simple and fast. However, metallization of this kind has the disadvantage in having a lower aspect ratio and higher contact resistance, limiting solar cell efficiency. The mounting cost of silver pastes and decreasing silicon wafer thicknesses encourages silicon solar cell manufacturers to develop fresh metallization techniques that involve a lower quantity of silver usage with no need to rely on the pressing process of screen printing. The photovoltaic industry also needs for solar cells to have superior performance with a lower usage of silver pastes, as has been set out by the international technology roadmap for photovoltaics (ITRPV) [1]. In this regard, a great deal of investigation has already been conducted on different metallization techniques as an alternative to screen printing technology. The growth of metallization techniques with minor production costs and higher efficiencies is critical for the progression of solar cell manufacturing technology. These facts has been realized and a workshop dedicated for the metallization of crystalline silicon solar cells has been organized for the first time in Utrecht, The Netherlands, in 2008 [2]. After the first successful workshop, the series [3,4] was continued, and the fourth metallization workshop was held more recently in Constance, Germany, in May 2013 [5]. All of these workshops have helped improve understanding of the current state and recent advances of metallization technology.

Among the promising metallization techniques, the formation of metal contacts using $\mathrm{Ni} / \mathrm{Cu}$ plating techniques is assumed to be one of the most viable candidates for future use as contact technology for the manufacture of solar cells. Using $\mathrm{Ni} / \mathrm{Cu}$ plating techniques is a good solution to improve the efficiency of metallization processes with precision and low contact resistance. The technique can be realized at lower material costs, and is suitable for use in mass production. The standard processing sequence of $\mathrm{Ni} / \mathrm{Cu}$ contact formation involves two steps: in the first step, (i) Ni metal film is plated on to the solar cell surface, followed by (ii) the final step of plating a copper metal film on top of the Ni. This $\mathrm{Cu}$ film over the $\mathrm{Ni}$ film serves as a conduction layer/contact for the solar cell [6-10]. The formation of metal contacts using electroplating processes is a well-developed technique that can only be used for conductors. As the electroplating process cannot be realized on semiconductors, an auto-catalytic method of Ni electroless plating (used to deposit nickel phosphorus or nickel boron) has to be adopted in order to make contacts for the semiconducting surface of the cell. This Ni electroless plating method has already been assessed and broadly employed in the formation of contacts for silicon solar cells [11-13]. The use of $\mathrm{Ni}$ as a seed layer makes it possible for metals to be plated on semiconducting or non-conducting materials. The process of $\mathrm{Ni}$ electroless plating requires a complexing agent, a buffer agent and a reducing agent that reacts with metal ions to form metal film. Apart from the conventional electroless plating of $\mathrm{Ni}$ seed layer, it is plated in the presence of illumination, referred to as light induced electroless plating (LIEP) [14,15].

The approach of light induced plating (LIP) [16,17] developed by Fraunhofer ISE, is adopted and widely used for plating the silicon solar cell by many research groups. In the process of the LIP technique, a sample composed of $\mathrm{n} / \mathrm{p}$ junction and an aluminum back contact formed by screen printing is immersed in a plating bath. The sample immersed in the plating solution is applied with a protective potential, so that rear of the cell can be made more cathodic, which results in the lowering of 
the aluminum corrosion. The protective potential not only prevents the erosion of aluminum but also helps to operate the cell closer to short circuit conditions and hence increases the plating uniformity [18]. The applied bias increases the operating current density of the cell, resulting in faster plating rates. The LIP arrangement is useful in controlling the height of the plated metal finger by varying the intensity of light or process velocity speed. Moreover, the LIP is considered to be favorable for the metallization of solar cells, as the metallization for the front grid as well as the fully aluminum doped rear side can be achieved at the same time. The schematic of such $\mathrm{Cu}$ based LIP plating process is shown in Figure 1.

In this paper a detailed overview of the metallization technology based on the $\mathrm{Ni} / \mathrm{Cu}$ plating process will be given. The experimental procedures involved for $\mathrm{Ni}$ seed layer formation by various methods and LIP $\mathrm{Cu}$ plating will be discussed. Moreover, the current and future prospects of such low cost metallization technology for crystalline silicon solar cells will be addressed.

Figure 1. Schematic diagram of the light induced plating (LIP) based $\mathrm{Cu}$ electroplating process [16].

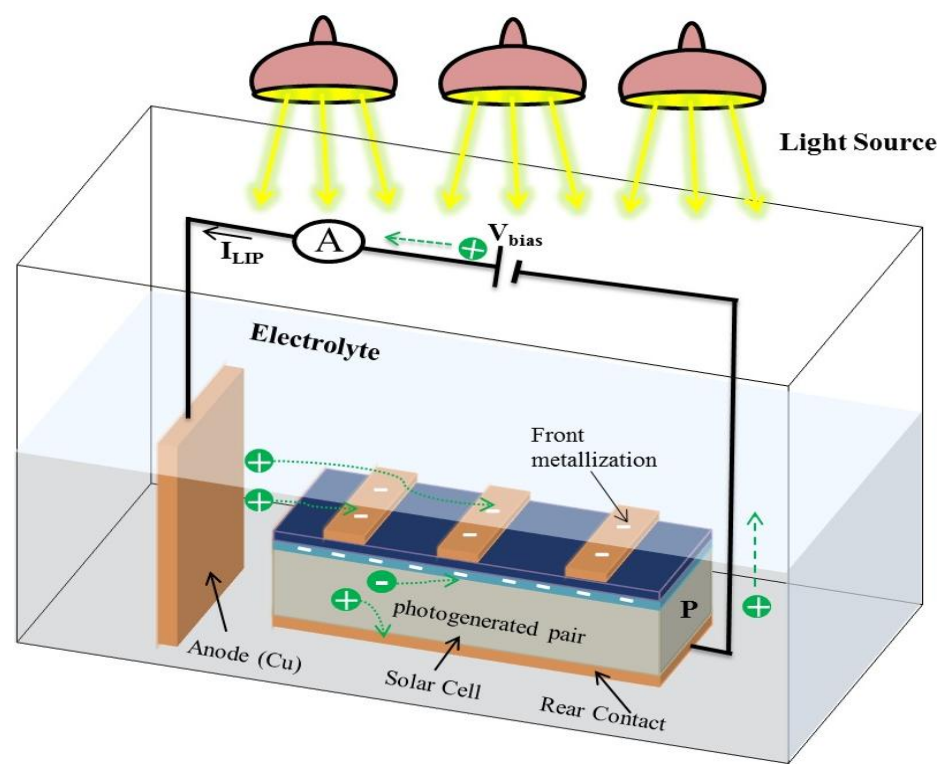

\section{Need for an Alternate Metallization Scheme}

The contact formation by the screen printing technique is most widely used for the crystalline silicon solar cells production. The key feature is higher through put with simple processing steps of co-firing the front and rear of the cells. Photovoltaic modules with efficiencies looming $19 \%$ can be realized for mono type crystalline silicon solar cells. However, there are certain factors involved with screen printed contacts that tend to limit solar cell performance. Factors such as fill factor and finger widths are the major ones. The fill factor for screen printed cells typically lies in the range of $75 \%-78 \%$, which is because of the high contact resistance, lower metal conductivity and junction shunting presented by screen printed contacts. On the other hand, a fill factor of $81 \%-82 \%$ can be achieved with metallization based on a photolithographic process $[19,20]$. The finger widths of screen printed metallized solar cells are typically $\geq 100 \mu \mathrm{m}$, which contributes to an increase in shading loss. Shading losses can be decreased by lowering the widths with a double print (print-on-print) 
technique [21-23]. The print-on-print technique can increase cell efficiency by lowering the widths; however, the alignment issues still limit the high throughput production on an industrial scale.

The cost of metallization plays a vital role and is one of the most important economic factors in today's industrial photovoltaic production. A report from Fraunhofer ISE indicates that up to $40 \%$ of cell processing costs is consumed by using expensive Ag paste [24]. An overall decrease in the price index for the solar module has occurred globally. Figure 2 shows the module price evolution in Germany, China, and Japan from January 2011 to June 2013 [25]. The photovoltaic business therefore requires an alternate scheme of metallization, as the mounting price of $\mathrm{Ag}$ affects it adversely.

Figure 2. Development in the photovoltaic module prices in China, Germany and Japan.

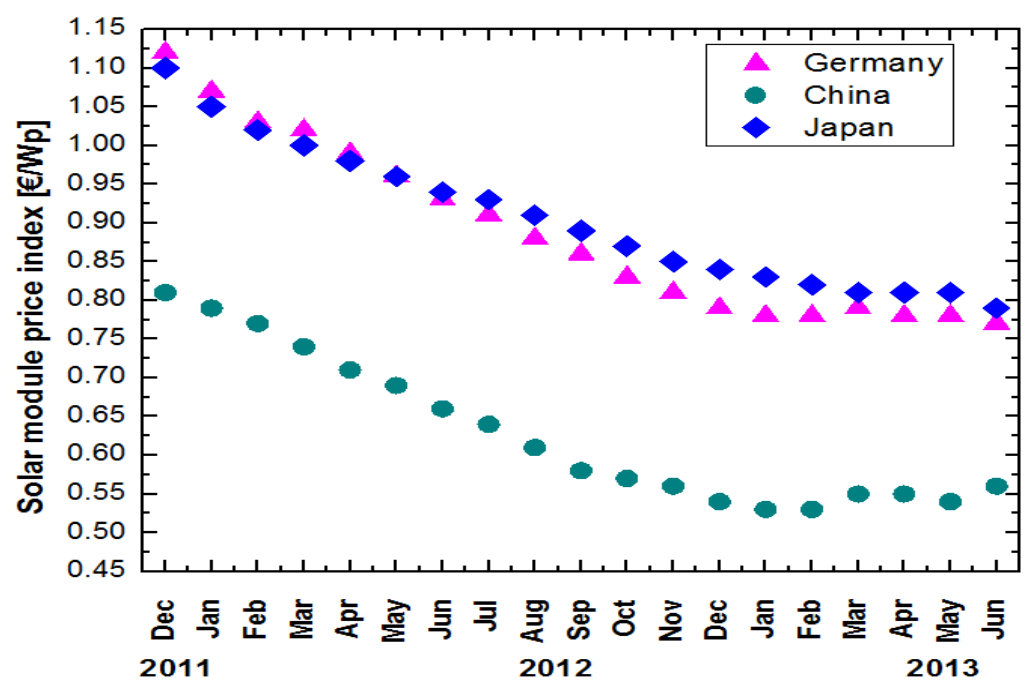

The limitations of screen printed contacts in respect to lower fill factors, higher shading losses and the use of expensive Ag pastes specifically displays the need for an alternate metallization scheme. In order to produce high performance solar cells, several efforts including selective emitters, buried contacts cell structure, inter-digitated back contacts (IBC) and passivated emitter rear locally diffused (PERL) structure have already been tried [26,27]. A higher efficiency of $25 \%$ has already been achieved with the PERL structure [28]. However, the development of such a structure is expensive and too complex for commercialization. $\mathrm{A} \mathrm{Ni} / \mathrm{Cu}$ based metallization scheme has emerged as a future candidate for crystalline based silicon solar cells. The contacts formed by using such $\mathrm{Ni} / \mathrm{Cu}$ based metallization can ensure improved results in terms of fill factors and efficiencies in comparison to conventional screen printed cells. The $\mathrm{Ni} / \mathrm{Cu}$ metallization for silicon solar cells may not only produce a high performance solar cell but can also reduce the processing costs. By looking upon the incentives of relatively cheaper but almost equal conductive copper, companies and many research institutes have already started to adopt it as an alternate metallization scheme. Copper has a conductivity almost equal to $\mathrm{Ag}$ paste but is cheaper (nearly 100 times) than $\mathrm{Ag}$ (Table 1). Moreover, the $\mathrm{Ni} / \mathrm{Cu}$ altogether offers 2.5 times higher electrical conductivity and lower contact resistance at lower doping concentrations (Ns) in comparison to the conductivity offered by Ag paste for silicon solar cells [29]. Apart from the cost and conductivity, finer line widths can be made because of the self-aligned plating process used in the $\mathrm{Cu}$ metallization scheme. The contacts are usually formed with processing in a relatively lower temperature range $\left(250-400{ }^{\circ} \mathrm{C}\right)$, which is considerably lower than the temperatures $\left(750-850{ }^{\circ} \mathrm{C}\right)$ 
needed for Ag pastes. The use of a lower temperature process during the $\mathrm{Cu}$ based metallization scheme is useful for passivation layers as higher temperature certainly degrades the passivation schemes as well as can melt $\mathrm{Al}$ rear contact. The use of such low cost materials for metallization can certainly lower the euro/ $W_{\mathrm{p}}$ price for solar cell modules. Copper, however, creates highly active recombination centers in silicon [30]; therefore, an effective barrier is required to prevent its diffusion in silicon. The $\mathrm{Ni}$ can form a promising barrier in between $\mathrm{Cu}$ and silicon, and it can also be useful in reducing contact resistance. A detailed comparison in terms of advantages and challenges for both metallization schemes is described in Table 2. The schematics in Figure 3 show the solar cell composed of metallization scheme based on screen printed $\mathrm{Ag}$ pastes and $\mathrm{Ni} / \mathrm{Cu} / \mathrm{Ag}$ plating technique. The next portion of the paper explains the processes involved in realizing such metallization scheme for silicon solar cells.

Table 1. Assessment of various metals costs and properties [31,32].

\begin{tabular}{cccc}
\hline Parameters & Ag & $\mathbf{C u}$ & $\mathbf{N i}$ \\
\hline Cost $[\$ /$ troy oz $]$ & 21.87 & 0.225 & 0.440 \\
Conductivity $\left[10^{6} \mathrm{~S} / \mathrm{m}\right]$ & 61.3 & 59.1 & 13.9 \\
$\rho\left[\mathrm{g} / \mathrm{cm}^{3}\right]$ & 10.49 & 8.92 & 0.50 \\
\hline
\end{tabular}

Figure 3. Solar cell structures composed of metallization scheme based on (a) Screen printed $\mathrm{Ag}$ paste; and (b) Ni/Cu/Ag plating.
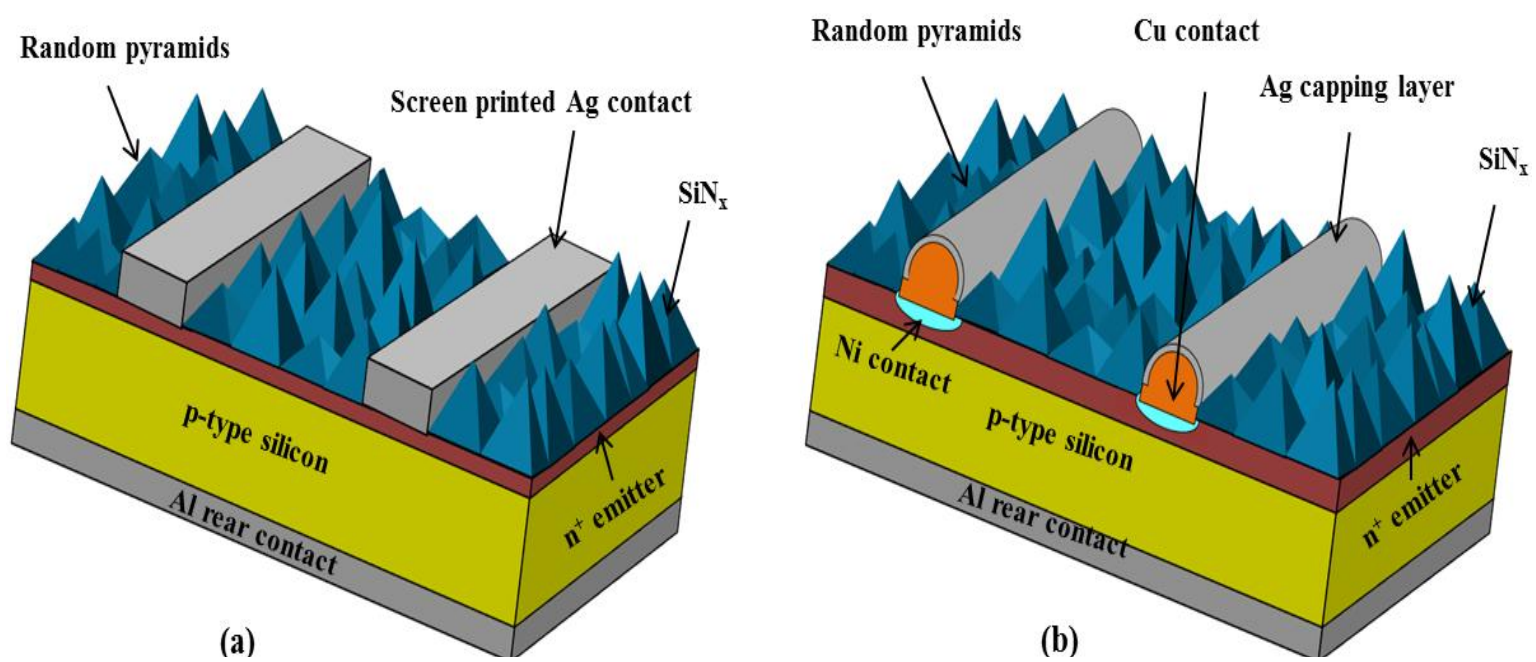

Table 2. Conventional Screen printed cells versus cells based on $\mathrm{Ni} / \mathrm{Cu}$ plating scheme.

\begin{tabular}{ccc}
\hline Metallization scheme & Benefits & Challenges \\
\hline \multirow{2}{*}{$\begin{array}{c}\text { Conventional Screen } \\
\text { printed cells }\end{array}$} & Simple process & Higher cost \\
& Speedy and mass production & Relatively low cell efficiency \\
& High contact resistance \\
& Low cost & Low aspect ratio \\
$\mathrm{Ni} / \mathrm{Cu}$ plated cells & High aspect ratio (decrease in shading losses) & Adhesion \\
& Low contact resistance & Back ground plating \\
& Higher efficiencies & Process complexity \\
\hline
\end{tabular}




\section{Ni/Cu Plating Technique}

The increase of attraction for Cu-based metallization for ultra large scale integrated circuits (ULSI) is due to its greater resistance against electron migration and lower electrical resistance. However, $\mathrm{Cu}$ as a contacting material has some major weaknesses for application in metallization schemes. The $\mathrm{Cu}$ atoms can travel effortlessly through the $\mathrm{SiO}_{2}$ layer to the $\mathrm{Si}$ substrate, and being a deep level impurity in $\mathrm{Si}$, it can disturb the electrical characteristics of the cell. The traps generated by these impurities act as generation and recombination centers, decreasing the minority carrier life-time in substrates [33,34]. To prevent the $\mathrm{Cu}$ from being diffused in the $\mathrm{Si}$, a diffusion barrier is required. $\mathrm{Ni}$ as a seed layer can promote adhesion between $\mathrm{Cu}$ and $\mathrm{Si}$ and it can act as a diffusion barrier to the migration of $\mathrm{Cu}$ atoms in to Si substrates [35]. The two step metallization concept (seed-layer + LIP concept) [36] is suitable for obtaining higher efficiencies. In the case of the $\mathrm{Ni} / \mathrm{Cu}$ plating technique, $\mathrm{Ni}$ can serve as a seed layer, while $\mathrm{Cu}$ as a main conducting layer can be deposited by electroplating technique. Thus the metallization technique, when using such an approach, involves two main steps:

i. Ni seed layer formation

ii. Cu electroplating technique

After depositing the $\mathrm{Ni} / \mathrm{Cu}$ stacks, a thin capping layer of tin ( $\mathrm{Sn}$ ) or silver (Ag) is generally deposited. This capping stack above $\mathrm{Cu}$ serves to protect these $\mathrm{Cu}$ conducting lines from being oxidized and to facilitate the soldering of interconnecting tabs. An additional significant aspect of the capping layer is that it avoids the interaction between the $\mathrm{Cu}$ and EVA encapsulant. The steps involved to form the metallization scheme composed of $\mathrm{Ni} / \mathrm{Cu} / \mathrm{Sn}$ or $\mathrm{Ag}$ stacks are shown in Figure 4.

Figure 4. Steps involved in formation of the metallization scheme based on $\mathrm{Ni} / \mathrm{Cu} / \mathrm{Sn}$ or Ag metallization scheme.

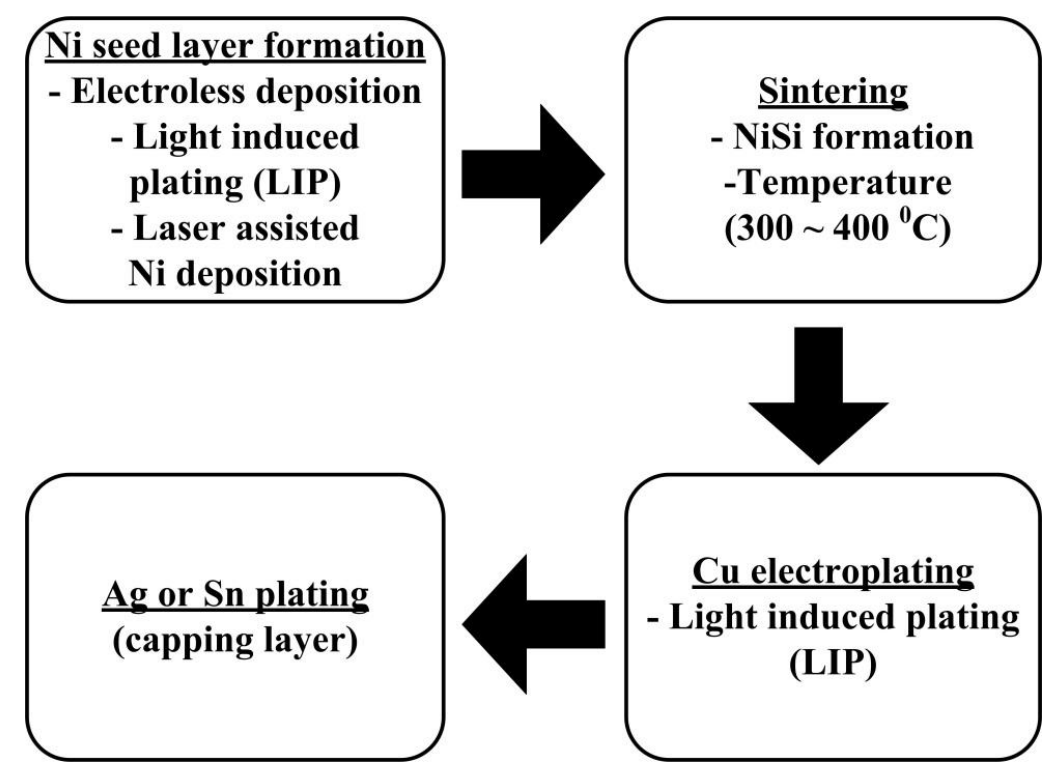

\subsection{Ni Seed Layer Formation}

In the first step, $\mathrm{Ni}$ as a metal seed layer can be formed by either method such as electroless plating technique, light induced plating or laser assisted deposition. Besides Ni, other transition metals such as 
titanium (Ti) or tungsten (W) can also be used as a seed layer. Nickel is the most suitable candidate since it works well as a diffusion barrier to $\mathrm{Cu}$ as well as providing the low contact resistance to doped silicon. The Ni electroless deposition along with low temperature anneal provided an opportunity to form low resistivity ohmic contact layers [37,38]. There are a number of ways to perform the electroless plating process by adopting the concept of the oxidation reduction reaction. The plating rates can be varied significantly by using a light assisted plating (LIP) technique [39]. Another very effective way to deposit the Ni seed layer is by using the laser assisted Ni deposition technique [40]. The method is very much advantageous as the anti-reflection coating (ARC), ablation step can be performed along with the formation of the Ni seed layer. The adequate thickness and evenness over the entire front side patterned grid are the basic requirements for depositing an effective Ni barrier layer. The prevention of copper from being diffused for a desired lifetime defines the effectiveness of the barrier layer. However, a thinner Ni layer is favored as the Ni conductivity is low in comparison to $\mathrm{Cu}$.

\subsubsection{Electroless Plating}

The Ni deposition process using an electroless plating technique is a well-established and suitable process. It is an autocatalytic process that does not rely on the application of electrodes potential to sample. The reaction taking place during the deposition process involves the reduction of metals cations by means of electrons supplied by the reducing agent. The plating bath for Ni electroless plating is composed of the following bath compositions, including reducing agent of sodium hypophosphite [41]:

- Nickel chloride, $\left(\mathrm{NiCl}_{2} \cdot 6 \mathrm{H}_{2} \mathrm{O}\right)$ or nickel sulfate, $\left(\mathrm{NiSO}_{4}\left[\mathrm{H}_{2} \mathrm{O}\right]_{6}\right)$ as a main source of $\mathrm{Ni}$

- Sodium hypophosphite, $\left(\mathrm{NaH}_{2} \mathrm{PO}_{2} \cdot \mathrm{H}_{2} \mathrm{O}\right)$ as a reducing agent

- Triammonium citrate $\left[\left(\mathrm{NH}_{4}\right)_{3} \mathrm{C}_{6} \mathrm{H}_{5} \mathrm{O}_{7}\right]$ as a buffer and mild complex agent for $\mathrm{Ni}$

The addition of ammonium hydroxide $\left(\mathrm{NH}_{4} \mathrm{OH}\right)$ is also required in order to maintain the $\mathrm{PH}$ value in between 8 and 10 [6,11]. This plating process is based on a catalytic oxidation-reduction reaction between hypophosphite ions and $\mathrm{Ni}$. The chemical reaction can be described as the sum of two simultaneous steps. The steps are outlined as follows:

$$
\begin{gathered}
\text { Step (1): } \mathrm{H}_{2} \mathrm{PO}_{2}^{-}+\mathrm{H}_{2} \mathrm{O} \rightarrow \mathrm{HPO}_{3}^{2-}+2 \mathrm{H}^{+}+\mathrm{H}^{-} \\
\text {Step (2): } 2 \mathrm{H}^{-}+\mathrm{Ni}^{2+} \rightarrow \mathrm{Ni}+\mathrm{H}_{2} \\
\text { Sum: } 2 \mathrm{H}_{2} \mathrm{PO}_{2}^{-}+2 \mathrm{H}_{2} \mathrm{O}+\mathrm{Ni}^{2+} \rightarrow \mathrm{Ni}+\mathrm{H}_{2}+4 \mathrm{H}^{+}+2 \mathrm{HPO}_{3}^{2-}
\end{gathered}
$$

\subsubsection{Light Induced Plating (LIP)}

Light induced plating (LIP) baths were used for the formation of $\mathrm{Ni}$ as a seed layer. The chemical reactions (catalytic oxidation-reduction) taking place during the LIP Ni deposition process are the same as for the electroless plating bath outlined in the previous section. However, the inclusion of a light source helps to adjust the electrochemical potential of the front and rear of the cell and increases the plating rates [42]. The photo voltage by the PN junction and the electronegativity of the substrates accommodate to govern the electron migration at the surface. Furthermore, the diffusion of these photo-generated electrons at the surface helps in the reduction of $\mathrm{Ni}^{2+}$ ions and contributes in the form 
of higher plating rates [12]. The chemical baths can be operated at relatively lower temperatures with the addition of a light source in comparison to conventional electroless plating (non-LIP). Yu-Han et al., demonstrate light induced nickel plating (LINP) for p-type substrates having uniform metal surfaces and high intrinsic quality [14]. Apart, from higher plating rates with uniform metal surfaces, the process involves the difficulty associated with the process characterization, as well as the dependence of plating on cell performance [18].

\subsubsection{Laser Assisted Ni Deposition}

The use of lasers for depositing $\mathrm{Ni}$ as a seed layer has the advantage of using a single step for opening the ARC as well as the seed layer formation. The process involves the immersion of the solar cell in to an electrolyte solution and the application of a laser to write the grid from above. The working principle of laser induced $\mathrm{Ni}$ deposition from an aqueous electrolyte solution depends on the temperature rise produced by the laser in the solution and the wafer [40]. Because of the heat produced at the wafer surface the ARC is ablated at the area exposed and the temperature rise in the electrolyte initiates decomposition of Ni particles. Moreover, at the same time, an electron hole pair generation occurs in the solar cell by the light induced. The generated electron moves to the top surface and favors the Ni deposition. A uniform quantity of metal throughout the process is required to deposit a worthy $\mathrm{Ni}$ layer by the laser induced process. The water containing $\mathrm{Ni}$ salts could be helpful for the homogeneous coating of the wafers. Although, the experience in laser induced deposition from liquids still needs to be developed, there has been some research in this area [43-45]. The ARC ablation step along with the Ni deposition process by means of the laser chemical metal deposition (LCMD) process can play a critical role in commercialization of $\mathrm{Ni} / \mathrm{Cu}$ metallization for silicon solar cells. At Fraunhofer ISE, the LCMD process was applied for depositing Ni along with a nitride ablation step and followed by a $\mathrm{Cu}$ plating step [46]. Another laser based metal deposition process called laser transfer contact (LTC) was also used to deposit an Ni seed layer through an optically transparent glass and finger widths of less than $30 \mathrm{~nm}$ was achieved [47].

\subsubsection{Ni Silicide Formation}

A process known as a sintering process whereby heating in the ambiance of $\mathrm{N}_{2}$ gas is next to follow after $\mathrm{Ni}$ deposition which forms an alloy of $\mathrm{Ni}$ and silicon. The alloy formed acts as seed layers for $\mathrm{Cu}$, which is usually prepared at higher temperatures $\left(300-400{ }^{\circ} \mathrm{C}\right)$. This results in a reduction in metal semiconductor contact resistance [35]. The resistivity of Ni silicide is $14 \mu \Omega$.cm, which is comparable to Ti silicide (13-16 $\mu \Omega . \mathrm{cm})$ [6]. The $\mathrm{Ni}$ forms various phases with different compositions when heated at various temperature ranges, such as $\mathrm{Ni}_{2} \mathrm{Si}\left(200-300{ }^{\circ} \mathrm{C}\right)$, NiSi $\left(300-700{ }^{\circ} \mathrm{C}\right)$ and $\mathrm{NiSi}_{2}\left(700-900{ }^{\circ} \mathrm{C}\right)$ [48]. The NiSi phase is identified as forming a lower resistivity state, and for that reason is beneficial for the metallization of silicon solar cells. The Ni plating process presented by Mondon et al. at 2nd workshop on metallization has been considered as a reference and is shown in Figure 5. 
Figure 5. Plating of Ni by electrochemical deposition done by Mondon et al. at Fraunhofer ISE and presented at the 2nd metallization workshop for crystalline silicon solar cells, reprinted with permission from the authors (2014) [49].

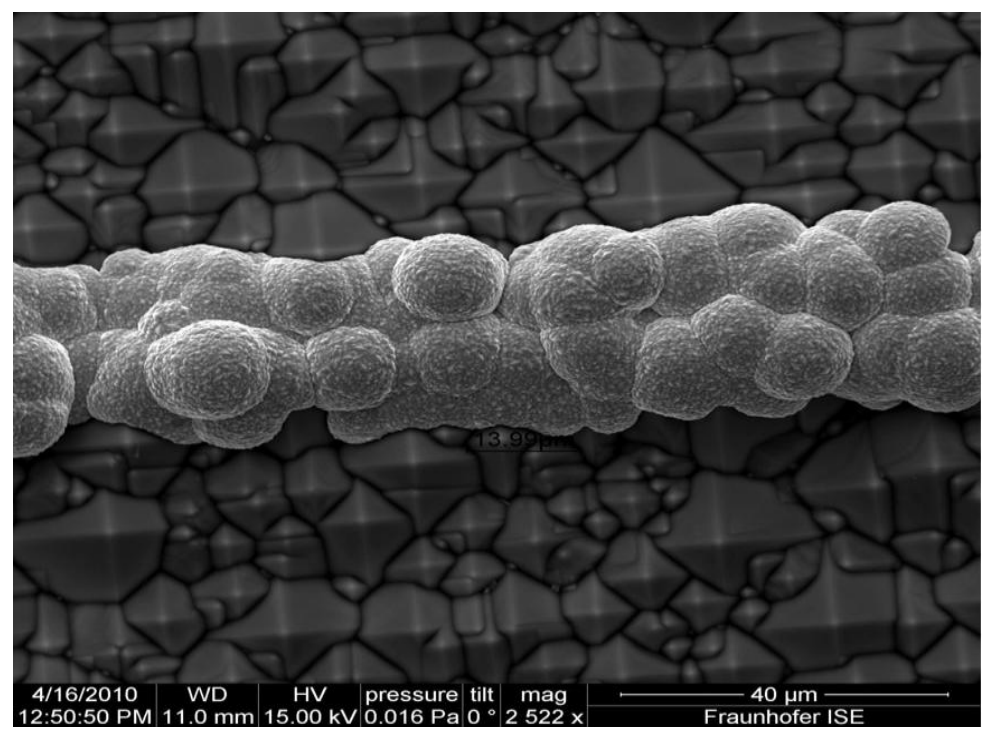

\section{2. $\mathrm{Cu}$ Electroplating Process}

$\mathrm{Cu}$ electroplating is usually done by the light induced plating (LIP) technique. The schematic in Figure 1 explains the working principle of the LIP process. The LIP technique involves the immersion of solar cell in an illuminated electroplating bath operated at room temperature. $\mathrm{A} \mathrm{Cu}$ anode is placed in to the electrolyte bath, which is connected to the positive electrode of a dc voltage source. The sample (solar cell) is connected to the negative electrode of the battery. The electrolyte bath is composed of cupric sulfate, which helps in supplying copper ion $\left(\mathrm{Cu}^{2+}\right)$, needed for the plating. The negative potential connected to the solar cell emitter helps the $\mathrm{Cu}$ ions to be attracted to the front metallized area. The photo-generated electrons in the samples recombine with the $\mathrm{Cu}$ ions and then the $\mathrm{Cu}$ is deposited on the existing metal stack ( $\mathrm{Ni}$ seed layer). The main additives of the Cu plating bath are composed of cupric sulfate $\left(\mathrm{CuSO}_{4} \cdot 5 \mathrm{H}_{2} \mathrm{O}\right)$ and sulfuric acid $\left(\mathrm{H}_{2} \mathrm{SO}_{4}\right)$. The sulfuric acid plays a role of inducing the current flow at low voltage to increase conductivity [50]. The $\mathrm{Cu}$ deposition only occurs on the conductive surface, meaning not on the ARC covered areas but at the opened areas. The reactions taking place at each electrode during the $\mathrm{Cu}$ plating process are summarized in Table 3.

Table 3. Reactions taking place at anode $(\mathrm{Cu})$, electrolyte solution $\left(\mathrm{H}_{2} \mathrm{SO}_{4} / \mathrm{CuSO}_{4}\right)$ and cathode (substrate).

\begin{tabular}{ccc}
\hline No. & Reaction places & Reaction \\
\hline 1$)$ & Anode $(\mathrm{Cu}$ metal $)$ & $\mathrm{Cu}+2 \mathrm{e}^{+} \rightarrow \mathrm{Cu}^{2+}$ \\
$2)$ & Solution & $\mathrm{CuSO}_{4} \rightarrow \mathrm{Cu}^{2+}+\mathrm{SO}_{4}^{2-}$ \\
$3)$ & Cathode (substrate) & $\mathrm{H}_{2} \mathrm{SO}_{4} \rightarrow 2 \mathrm{H}^{+}+\mathrm{SO}_{4}^{2-}$ \\
$\mathrm{Cu}^{2+}+2 \mathrm{e}^{-} \rightarrow \mathrm{Cu}$ \\
\hline
\end{tabular}

The working principle of LIP is same as the conventional plating process with the utilization of the photo-generation property of the solar cell. The LIP in comparison to conventional electro/electroless 
plating techniques has the advantages of having a uniform voltage distribution across the grid pattern (ensures a uniform current density) with stable baths (no reducing agents). Moreover, LIP is favorable particularly in the case of solar cell metallization, since it can perform the plating process for the front contact grids and can metallize the fully aluminum doped rear side of the cell. Higher aspect ratios and larger deposition rates (in the range of $0.1-2 \mu \mathrm{m} / \mathrm{min}$ ) can also be achieved. These deposition rates can be controlled by observing the current $\left(I_{\text {LIP }}\right)$ in the external circuits as well as by regulating the light irradiance during the LIP process. An increase in the deposition rates can be achieved with higher $I_{\text {LIP }}$ currents and larger light irradiance. However, at higher deposition rates the deposited material quality is poorer (higher porosity) as compared to the LIP process at lower rates [51]. Figure 6 shows SEM image for $\mathrm{Ni} / \mathrm{Cu} / \mathrm{Ag}$ stacks processed at $\mathrm{MECO}$ by Tous et al [52].

Figure 6. Scanning electron microscopy (SEM) images of the plated lines processed at MECO. Focus ion beam (FIB) cutting was used to analyze the cross-sectional images of the plated lines. The electroplated copper above nickel layer is covered by Ag capping layer at the top, reprinted with permission from the authors (2014) [52].

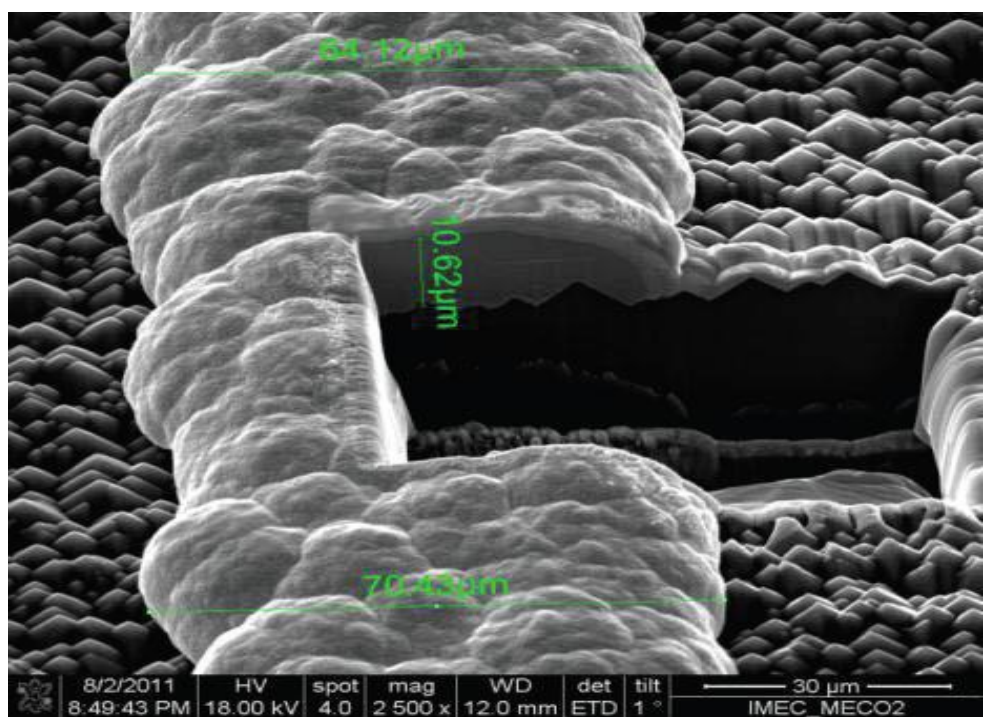

\section{Experimental Section}

The sample composed of an $\mathrm{n} / \mathrm{p}$ junction has to be submerged in the solutions containing the $\mathrm{Ni}$ electroless plating solution, followed by sintering process, to prepare a seed layer for Cu plating. Prior to performing the Ni electroless plating process, the ARC (anti reflection coating) has to be opened. There are a number of methods that can be used to open the ARC. One such method is the mask and etch sequence. Here the photoresist mask is patterned initially by using a photolithography process. The unprotected ARC is then etched away exposing the emitter area. The etching of ARC is usually done by the use of hydrofluoric acid followed by the striping of the mask layer by an organic solvent. The photolithography process which can be used for patterning the mask layer has the ability to pattern lines with lower widths. The schematics in Figure 7 show a mask and etch sequence that can be adapted for patterning the contacts for silicon solar cells.

After the ARC opening, Ni can be plated on exposed area for the formation of a seed layer. The electroless plating or LIP bath consisting of a Ni source in the form of metal salt $\left(\mathrm{NiCl}_{2}\right.$ and $\left.\mathrm{NaH}_{2} \mathrm{PO}_{2}\right)$, 
performs the process of forming this $\mathrm{Ni}$ metal layer. The $\mathrm{Ni}$ metal begins to deposit on the silicon surface in the form of the $\mathrm{Ni}$ layer [53]. The Ni layer deposited needs to be sintered at lower temperature in order to form $\mathrm{Ni}$ silicide [54]. Min et al. worked on optimizing the nickel sintering process and were able to manufacture $18.15 \%$ efficient PESC (passivated emitter solar cell) cell with selective emitters [55]. Cu electroplating using the LIP technique is the next step to be performed after the seed layer. The schematics in Figure 8 show a contact structure that can be formed by plating $\mathrm{Ni}$ and $\mathrm{Cu}$ followed by Tin $(\mathrm{Sn})$ or $\mathrm{Ag}$ a capping layer. The SEM image in Figure 9 shows the mechanically polished $\mathrm{NiSi} / \mathrm{Ni} / \mathrm{Cu}$ stacks formed on textured silicon surface presented by Nguyen et al. [56].

Figure 7. Schematic mask and etch sequence. Mask patterning is done initially to open ARC followed by a process of photoresist removal.

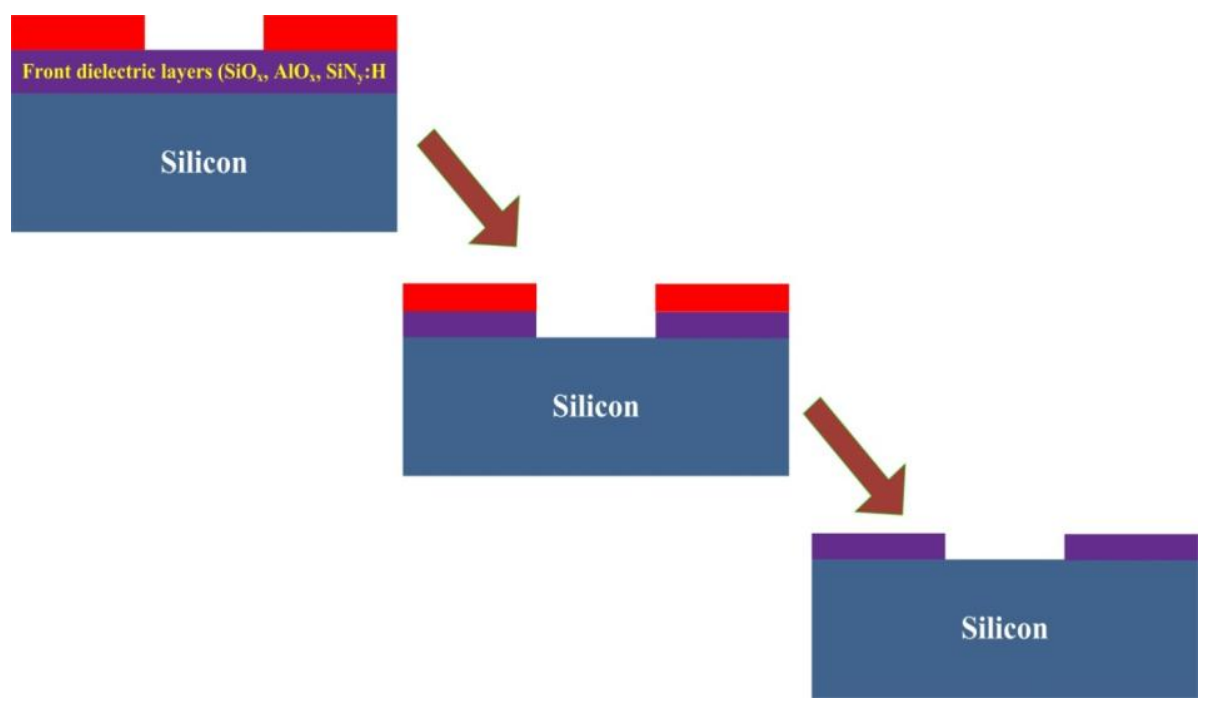

Figure 8. Schematic structures for the steps involved in the formation of metallization scheme based on $\mathrm{Ni} / \mathrm{Cu} / \mathrm{Sn}$ or $\mathrm{Ag}$ stacks.

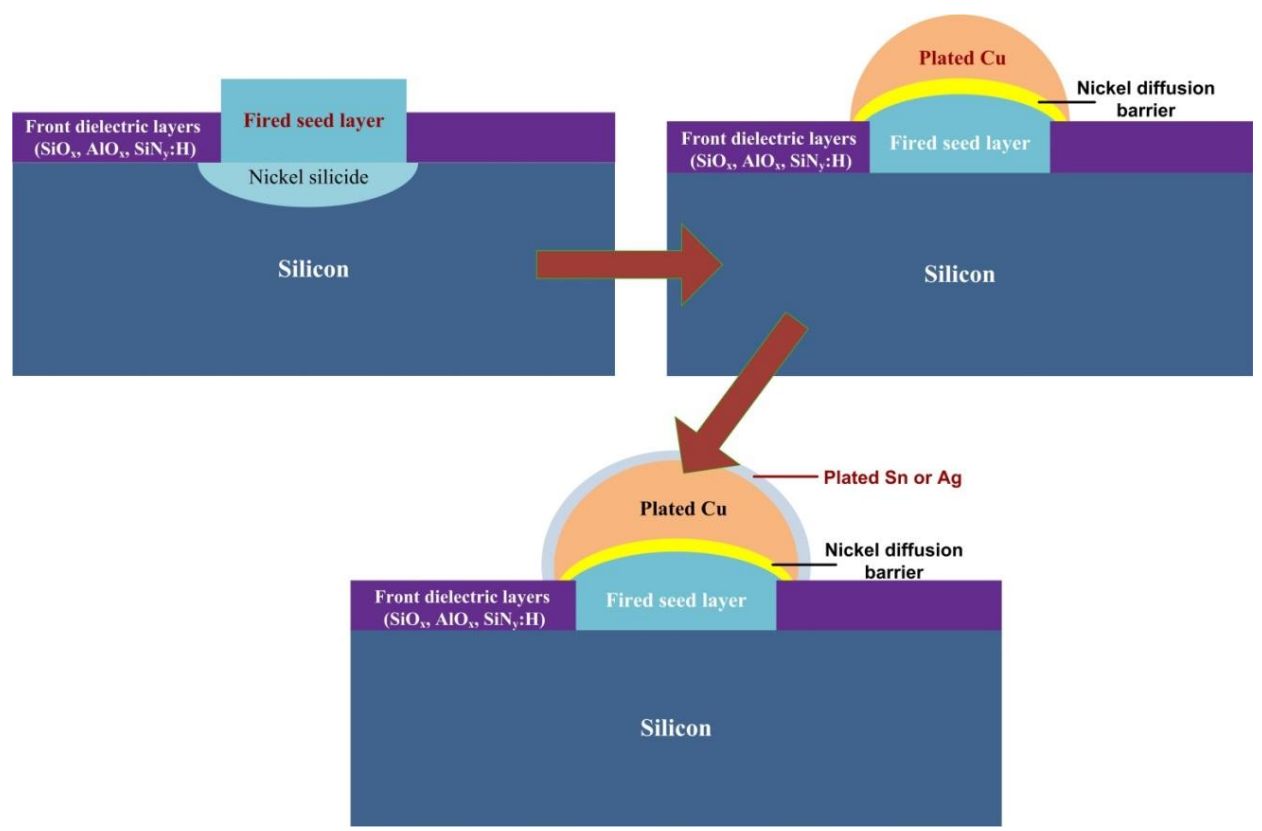


The photolithographic based ARC opening method has the ability to pattern the lines with lower widths. However, the number of processing steps involved in such a method can limit the high throughput desirable for commercialization. There are a number of methods other than the photolithography process that has been applied for opening the ARC. The methods include the use of an etching pastes [57-59], laser transferred $\mathrm{Ni}$ seed layers [60], ARC opening by mechanical scribing [9] and aerosol jet for etching [61,62]. The use of the laser chemical metal deposition (LCMD) process is considered to be the most suitable process for industrial application. The method can certainly make the process simpler, as the nitride ablation and seed layer formation can be performed in a single step $[43,44]$. N. Wehkamp et al. at Fraunhofer ISE have worked on such type of laser chemical metal deposition methods, and reported an efficiency of $17.9 \%$ by forming a $40 \mu \mathrm{m}$ wide line for solar cell fabricated on p-type CZ silicon substrate [46].

Figure 9. SEM cross sectional image of a mechanically polished $\mathrm{NiSi} / \mathrm{Ni} / \mathrm{Cu}$ stacks on textured silicon presented by Nguyen et al., with permission from European Photovoltaic Solar Energy Conference (EUPVSEC), copyright and permission section (2013) [59].

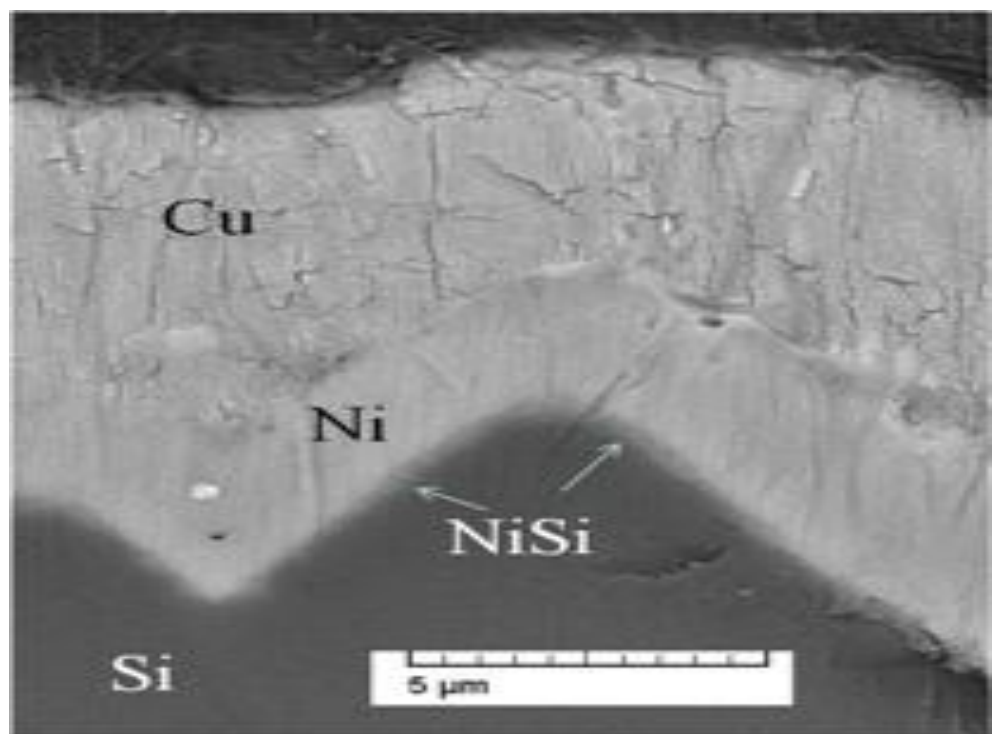

\section{Cu Plating Contributions}

In spite of the potential benefits of $\mathrm{Ni} / \mathrm{Cu}$ contacts, its commercialization has been limited thus far. BP Solar has been alone producing laser grooved buried grid (LGBG) type cells between the years 1992 and 2008 [63]. The increased process complexity and convenience for the use of appropriate low cost production techniques are the primary reasons restricting its commercialization. $\mathrm{The} \mathrm{Ni} / \mathrm{Cu}$ as a front contact however, has been investigated by many research institutes including, Fraunhofer ISE [6-8,55,64-69]. The advancements in new cost effective patterning techniques and biased assisted light induced $\mathrm{Ni} / \mathrm{Cu}$ plating have come up with solutions for complications and have helped in realizing practical low cost contacts that do not rely on Ag screen printing. In recent years, efficiencies of over $20 \%$ have been reported by various companies (Hyundai Heavy Industries, Kaneka, Schott Solar, Silevo, SunTech, TetraSun) and research institutes (Fraunhofer ISE, IMEC, Roth \& Rau Research) with the cells based on $\mathrm{Cu}$ metallization. The investigation for cell structures, such as 
Heterojunction Cells, laser doped buried contacts (LDBG), laser doped selective emitter (LDSE) and passivated emitter and rear cell (PERC) type cells has been conducted for a metallization scheme based on the $\mathrm{Cu}$ plating technique. The process flow for LGBG type cells from BP Solar involves, laser grooving, $\mathrm{Ni}$ and $\mathrm{Cu}$ electroless plating followed by deposition of a thin $\mathrm{Ag}$ layer for solderability. Figure 10 shows cell structures of laser doped buried contact (LDBC), LDSE and PERC type solar cells that has been investigated for the $\mathrm{Ni} / \mathrm{Cu}$ based metallization scheme.

Figure 10. Solar cell structures most commonly adopted for $\mathrm{Ni} / \mathrm{Cu}$ based metallization scheme. (a) Laser doped buried contact (LDBC) cell; (b) Laser doped selective emitter (LDSE) cell; (c) Passivated emitter rear cell (PERC).

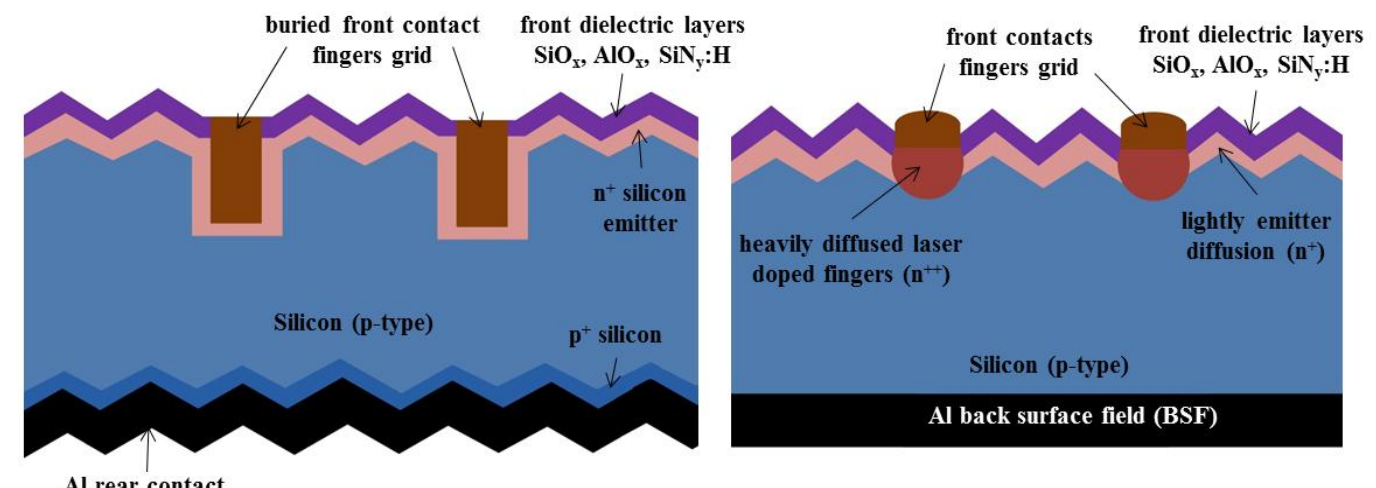

(a)

(b)

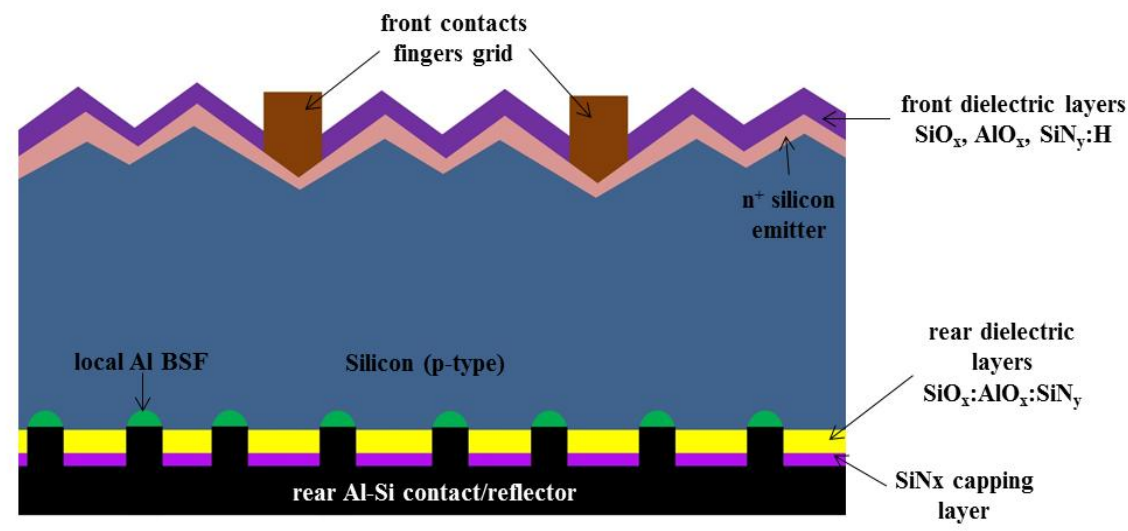

(c)

PERC type solar cell structures having efficiencies above $20 \%$ have already been demonstrated by several institutes with best cell efficiency of $21.4 \%$ at Fraunhofer ISE [70]. Schmid Group and Schott Solar demonstrated 20.9\% efficient PERC type cell with the front side electroplated with $\mathrm{Ni} / \mathrm{Cu}$ [71]. More recently, IMEC along with MECO presented i-PERC type solar cell [72]. The cells offer industry-applicable $\mathrm{Ni} / \mathrm{Cu}$ plated front contacts with an average of $20.5 \%$ efficiency (>100 cells) and with the best cell efficiency of $20.79 \%$ [73]. IMEC emphasized the parameters like cell efficiency, module reliability and euro/ $W_{\mathrm{p}}$ cost potential for i-PERC type cell by means of pilot-line processing tools. The research team was however successful in establishing of a simpler metallization sequence for $\mathrm{Ni} / \mathrm{Cu} / \mathrm{Ag}$ type contact having an advantage of minimal number of processing steps. The process flow of IMEC i-PERC type solar cell is shown in Figure 11. 
Figure 11. Process flow of PERC type solar cell processed at IMEC [73].

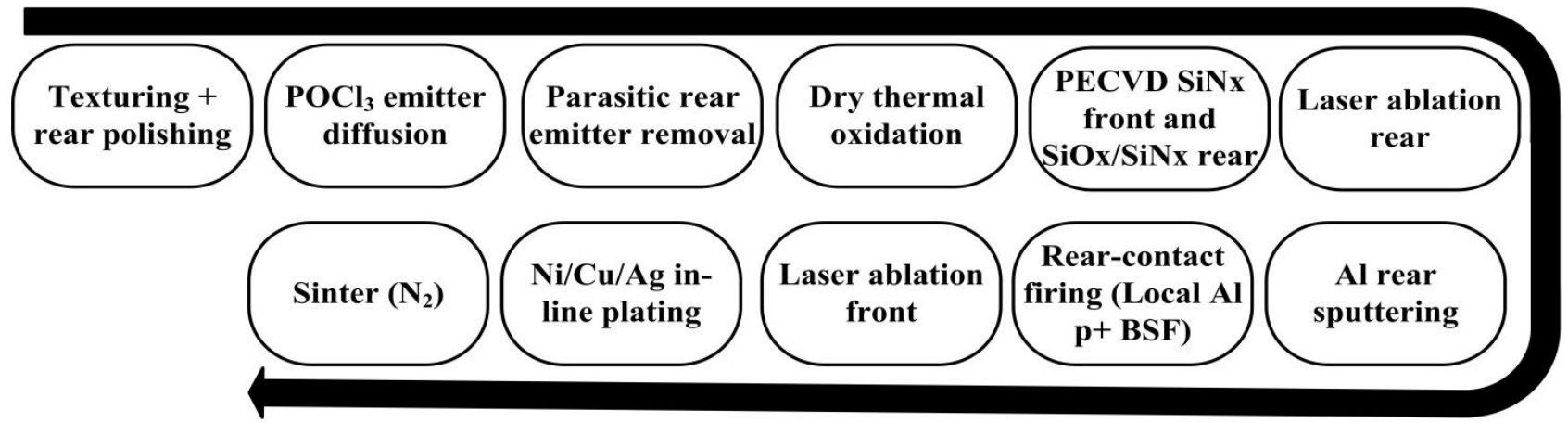

The LDSE cell concept was pioneered at the University of New South Wales (UNSW), Australia. Hyundai Heavy Industries, in Korea have presented such LDSE solar cells using Ni/Cu based front side metallization having $19.8 \%$ efficiency [74]. UNSW and Shinsung Solar Energy have also presented LDSE solar cells with $\mathrm{Ni} / \mathrm{Cu}$ based metallization with efficiencies of $19.3 \%$ and $19.6 \%$, respectively [75-77]. Apart from LDSE and PERC type cells, Suntech Power has produced Pluto cells with stabilized efficiencies of $19 \%$ for $\mathrm{Ni} / \mathrm{Cu}$ metallization [78]. Solar cell composed of $\mathrm{Cu}$ based metallization wrap through (MWT) cell structure was fabricated by Holger et al. at the University of Konstanz, Germany [7]. Kaneka and Roth \& Rao Research adopted the Cu contacts for Heterojunction type cells and presented higher efficiencies of $23.5 \%$ and $22.3 \%$ respectively $[79,80]$. Some of the optimal results for solar cells composed of $\mathrm{Cu}$ plated front contacts are summarized in Table 4.

Table 4. Optimal results for various high efficiency cell structures with front side metallized by the LIP based $\mathrm{Cu}$ plating technique.

\begin{tabular}{|c|c|c|c|c|c|c|c|}
\hline $\begin{array}{l}\text { R \& D } \\
\text { Centre }\end{array}$ & Type & Substrate & $\begin{array}{c}V_{\mathrm{oc}} \\
(\mathrm{mV})\end{array}$ & $\begin{array}{c}J_{\mathrm{sc}} \\
\left(\mathrm{mA} / \mathrm{cm}^{2}\right)\end{array}$ & $\begin{array}{c}\text { Fill Factor } \\
(\%)\end{array}$ & $\begin{array}{c}\text { Efficiency } \\
(\%)\end{array}$ & References \\
\hline Kaneka & Heterojunction & $\mathrm{CZ}$ & 737.0 & 39.97 & 79.77 & 23.50 & [79] \\
\hline $\begin{array}{c}\text { Roth \& Rau } \\
\text { Research }\end{array}$ & Heterojunction & - & 734.0 & 38.1 & 79.9 & 22.3 & [80] \\
\hline $\begin{array}{c}\text { Fraunhofer } \\
\text { ISE }\end{array}$ & PERC & FZ & 679.0 & 38.8 & 81.5 & 21.4 & [70] \\
\hline Schott Solar & PERC & $\mathrm{CZ}$ & 665.0 & 39.9 & 80.5 & 21.3 & [81] \\
\hline IMEC & PERC & $\mathrm{CZ}$ & 649.8 & 39.3 & 78.3 & 20.79 & [73] \\
\hline IMEC & Rear junction & $\mathrm{CZ}$ & 676 & 38.4 & 79.2 & 20.5 & {$[82]$} \\
\hline $\begin{array}{c}\text { Fraunhofer } \\
\text { ISE }\end{array}$ & - & FZ & 646.4 & 38.86 & 80.8 & 20.3 & [64] \\
\hline $\begin{array}{l}\text { Hyundai } \\
\text { Heavy } \\
\text { Industries }\end{array}$ & LDSE & $\mathrm{CZ}$ & 635.0 & 39.1 & 79.8 & 19.8 & [74] \\
\hline $\begin{array}{c}\text { Shinsung } \\
\text { Solar } \\
\text { Energy }\end{array}$ & LDSE & $\mathrm{CZ}$ & 644.0 & 38.75 & 78.72 & 19.64 & [76] \\
\hline IMEC & PERC & $\mathrm{CZ}$ & 655.9 & 38.3 & 77.8 & 19.6 & [52] \\
\hline UNSW & LDSE & $\mathrm{CZ}$ & 638.3 & 38.43 & 78.82 & 19.33 & [75] \\
\hline
\end{tabular}

Notes: $V_{\mathrm{oc}}$ : open circuit voltage; $J_{\mathrm{sc}}$ : short circuit current density. 


\section{Future Challenges}

Solar cells having superior performance at lower costs can be realized using the Ni/Cu plating approach. There has been good progress in various aspects of the process. Higher efficiencies (up to $21.4 \%$ ), can be achieved with such low cost metallization schemes [70]. While taking into account the advantage of high efficiency potential over screen printed cells the cost of ownership of Ni/Cu plating needs to be considered. Although the economic advantage of $\mathrm{Ni} / \mathrm{Cu}$ plated solar cells against their screen printed counterparts is striking. Yet, the plating process needs to be optimized entirely, in terms of cost and performance. If just the material price is considered, the saving potential is relatively high. However, consideration also has to be given to the additional process complexity and higher investment expenditure involved in replacing $\mathrm{Ag}$ printer/dryer with a setup comprising of laser, plating system and a sintering furnace. Nonetheless, in terms of material costs, $\mathrm{Ni} / \mathrm{Cu}$ may be advantageous given the current higher price of $\mathrm{Ag}$ and the fact that demands for it is expected to increase in years to come. In a recent report from IMEC, a cost estimation for both of these metallization schemes was made which clearly favored the $\mathrm{Ni} / \mathrm{Cu}$ plating scheme [73]. It is not only the cost of ownership but there are a number of issues to be resolved before a standard industrial process is presented. The major issues are (i) formation of a Ni seed layer uniformly, (ii) contact adhesion, (iii) back ground plating (iv) enhanced process complexity in comparison to Ag screen printing and more importantly the long term reliability.

\subsection{Uniform Ni Seed Layer}

The issue of depositing a uniform Ni layer is some extent solved by adopting processes such as electroless Ni plating [83] with a higher $\mathrm{pH}$ solution [84] and the light induced electroless plating method [14]. The use LIP for Ni plating bath may also be useful for faster plating rates and high throughput. Apart, from LIP the two staged (etching back unreacted $\mathrm{Ni}+$ replating step) is found to form a uniform Ni layer [85]. This method may not only form a uniform Ni layer but can also help to improve contact adhesion. A two-step Ni deposition process can also cover up the Si surface. For a complete covering of the Si surface an approach of depositing Ni seed layer with two steps Ni plating process, having a contact resistivity of $0.6 \mathrm{~m} \Omega . \mathrm{cm}^{2}$ has been demonstrated by Seran et al. at University of Konstanz, Germany [86].

\subsection{Contact Adhesion}

The problem of poor adhesion between metal and silicon is one of the main obstacles to the route of $\mathrm{Cu}$ based plating technology for solar cells. The justifications for low adherence have not been clarified completely. However, the use of seed layers, the environment for their realization and the progressive effects are well understood. The issue of improving the adhesion has been investigated by various research institutes $[52,85,87]$. The adhesion quality of the contacts formed can be assessed by performing various tests such as, a heat-quench test, a peel force test or pull strength tests. So far adhesions in the range 1-2.7 N/mm have been achieved for metallization based on $\mathrm{Ni} / \mathrm{Cu}$ stacks [52]. Formation of an adhesive Ni barrier was also investigated at Fraunhofer ISE, where a two stage process for contact formation was reported [85]. The process contains steps of etching back of 
unreacted Ni followed by a re-plating process. The adoption of this two stage process resolved the problem of low adherence of $\mathrm{Ni}$ to $\mathrm{Si}$ with an excellent adhesion of up to $2.5 \mathrm{~N} / \mathrm{mm}$ being achieved. The contact adhesion for $\mathrm{Cu}$ over $\mathrm{Ni}$ was also found to be influenced by the roles of bath ageing, acidity of the bath and cleanliness of the substrates. The acidic baths and an unclean surface affect the adhesion adversely while the stress present in films due to bath ageing has an impact on it as well $[88,89]$.

\subsection{Back Ground Plating}

Another challenge is the prevention of back ground plating also known as ghost plating or parasitic plating. The existence of impurities, particles and cracks on the wafer surface is mainly responsible for this phenomenon [90]. This effect has been noted when a number of pinholes are featured at the passivation layer. The plating occurs at these locations and results in undesirable shading and aesthetical deprivation of the solar cells. The presence of such plating affects the cell performance adversely. This can cause reduction in $J_{\text {sc }}$ due to shading of the front surface as well as junction shunting by the metal diffusion. Moreover, it may also lead to the increase in recombination velocity at the surface due to localized metal silicon contact. The primary causes of this unwanted phenomenon were demonstrated well by Barun et al., [91]. The unwanted plating was found to be mainly of two forms:

- $\quad$ Point like effects

- Cracks

The inhomogeneities of $\mathrm{SiN}_{x}: \mathrm{H}$ layers or the presence of silicon residuals were found mainly responsible for the generation of point like effects. However, the cracks which can be formed by mechanical stress (ultrasonic treatment) or insufficient texturing may also leads to the occurrence of the back ground plating of this type. This phenomenon of undesired plating on the tiny spots in the middle of fingers could be resolved by appropriate cleaning prior to $\mathrm{SiN}_{x}: \mathrm{H}$ deposition. The piranha solution $\left(\mathrm{H}_{2} \mathrm{O}_{2}+\mathrm{H}_{2} \mathrm{SO}_{4}\right)$ was found to be very effective for such treatment. The handling of the wafers (low mechanical stress during processing) is also very critical to avoid the unwanted metallization on cell surface $[91,92]$.

\subsection{Process Complexity}

The process complexity in comparison to the screen printed $\mathrm{Ag}$ metallization is also considered an issue for commercialization of $\mathrm{Ni} / \mathrm{Cu}$ plating technique. In order to form a potential $\mathrm{Cu}$ electrode and an effective $\mathrm{Ni}$ seed layer with sintering process increases the number of steps. However, implementing the $\mathrm{Ni} / \mathrm{Cu}$ technique for solar applications the reduction in the processing steps is highly demanded. A smarter approach could be combining a nitride ablation and a seed layer formation in a single step by using a laser process and a Ni electrolyte altogether [46]. Additionally, instead of electroless seed plating a faster and cheaper LIP technology can be adopted to create such contacts. The metallization process can be simplified further by applying the sintering process as a last step after full stack plating. At IMEC such thermal contact formation after $\mathrm{Ni} / \mathrm{Cu} / \mathrm{Ag}$ stacks formation were reported with promising results [93]. 


\subsection{Long Term Reliability}

One of the main issues restricting the commercialization of the $\mathrm{Ni} / \mathrm{Cu}$ based metallization process is the long term reliability of $\mathrm{Cu}$. $\mathrm{As} \mathrm{Cu}$ is a deep level impurity in $\mathrm{Si}$, it can have an impact on cell performance if it is being diffused in to $\mathrm{Si}$. In order to determine the reliability of the solar modules, an IEC 61215 test has to be carried out. The requirements are $\leq 5 \% p_{\max }$ loss after 200 thermal cycles $\left(-40^{\circ}\right.$ to $\left.85{ }^{\circ} \mathrm{C}\right)$ or $1000 \mathrm{~h}$ damp heat exposure $\left(85^{\circ} \mathrm{C}\right.$, 85\% relative humidity). Research institutes such as Fraunhofer ISE and IMEC have conducted such reliability tests and these were satisfactory up to a point. At Fraunhofer ISE, the pseudo fill factor (PFF) as measure for contamination was monitored for $1700 \mathrm{~h}$ at $200{ }^{\circ} \mathrm{C}$ temperature and the electrical performance was observed to be unchanged [70]. Meanwhile at IMEC, the modules made with $\mathrm{Ni} / \mathrm{Cu}$ metallization passed the reliability test (damp heat and thermal-cycling IEC 61215 extended tests), but this is still insufficient for long term reliability [73]. In another report, from Papet et al., a damp heat test was conducted for $\mathrm{Ni} / \mathrm{Cu}$ plated heterojunction cells showing only $3 \%$ of power degradation after $3000 \mathrm{~h}$ [80]. This shows the reliability of $\mathrm{Ni} / \mathrm{Cu}$ plating on heterojunction cells with time and temperature. Although, there have been some encouraging results in terms of reliability for cells comprised of $\mathrm{Ni} / \mathrm{Cu}$ contacts, complete testing is nevertheless required before industrial application.

\section{Conclusions}

The manufacturing costs of current silicon solar cells can be reduced by using inexpensive metals for metallization and thinner silicon substrates. This review has traced the prospective of $\mathrm{Ni} / \mathrm{Cu}$ plating technique for metallization of silicon solar cells. The use of $\mathrm{Ni}$ for promoting the adhesion and as a barrier to $\mathrm{Cu}$ shows great promise with many new plating techniques. $\mathrm{Cu}$ has the potential to become a major contributor as a cost effective material for future metallization schemes for silicon solar cells. Promising results in terms of higher fill factors and open circuit voltage during the last few years has been achieved. The advancement in new patterning technique such as the use of aerosol jet, laser doping and laser based chemical metal deposition has also occurred with the progression of plating techniques. A combination of nitride ablation and a $\mathrm{Ni}$ seed layer formation can be useful for the reduction in process complexity.

Metallization based on $\mathrm{Cu}$ plating appears to be a good alternative to existing screen printing technology in terms of material costs and cell performance. However, a standard industrial process is still limited by several hurdles. The challenges of adhesion, back ground plating, and process complexity has been resolved to a certain extent, however long term reliability is considered to be the primary obstacle to the sustainable manufacturing technology. The strong focus on the formation of reliable $\mathrm{Ni} / \mathrm{Cu}$ contacts can be inevitable for the prediction of ITRPV roadmap, of $\mathrm{Cu}$ being the future metal contact for silicon solar cells.

\section{Acknowledgments}

This work was supported by the New \& Renewable Energy Core Technology Program of the Korea Institute of Energy Technology Evaluation and Planning (KETEP), who granted the financial resource from the Ministry of Trade, Industry and Energy, Republic of Korea (No. 20133010011780). 


\section{Conflicts of Interest}

The authors declare no conflict of interest.

\section{References}

1. International Technology Roadmap for Photovoltaic (ITRPV) Home Page. Available online: http://www.itrpv.net/ (accessed on 15 September 2013).

2. First Work Shop on Metallization. Available online: http://www.metallizationworkshop.eu/previousworkshops/1st-edition/ (accessed on 15 September 2013).

3. Beaucarne, G.; Hoornstra, J.; Schubert, G. Lessons from the 2nd workshop on metallization of crystalline silicon solar cells. Futur. Photovolt. 2010, Available online: http://www.dowcorning.com/content/publishedlit/06-1055.pdf (accessed on 15 September 2013).

4. Beaucarne, G.; Schubert, G.; Hoornstra, J.; Horzel, J.; Glunz, S.W. Summary of the third workshop on metallization for crystalline silicon solar cells. Energy Procedia 2012, 21, 2-13.

5. Fourth Workshop on Metallization. Available online: http://www.metallizationworkshop.eu/home/ (accessed on 15 September 2013).

6. Kim, D.; Lee, E.; Kim, J.; Lee, S. Low-cost contact formation of high-efficiency crystalline silicon solar cells by plating. J. Korean Phys. Soc. 2005, 46, 1208-1212.

7. Knauss, H.; Terheiden, B.; Fath, P. Large-area metallisation wrap through solar cells using electroless plating. Solar Energy Mater. Solar Cells 2006, 90, 3232-3237.

8. Chaudhari, V.A.; Solanki, C.S. A novel two step metallization of Ni/Cu for low concentrator C-Si solar cells. Solar Energy Mater. Solar Cells 2010, 94, 2094-2101.

9. Lee, S. Cost effective process for high-efficiency solar cells. Solar Energy 2009, 83, 1285-1289.

10. Lee, E.; Kim, D.; Lee, S. Ni/Cu metallization for low-cost high-efficiency PERC cells. Solar Energy Mater. Solar Cells 2002, 74, 65-70.

11. Sullivan, M.V.; Eigler, J.H. Electroless nickel plating for making ohmic contacts to silicon. J. Electrochem. Soc. 1957, 104, 226-230.

12. Iwasa, H.; Yokozawa, M.; Teramoto, I. Electroless nickel plating on silicon. J. Electrochem. Soc. 1968, 115, 485-488.

13. Boulord, C.; Kaminski, A.; Canut, B.; Cardinal, S.; Lemiti, M. Electrical and structural characterization of electroless nickel-phosphorus contacts for silicon solar cell metallization. J. Electrochem. Soc. 2010, 157, H742-H745.

14. Su, Y.-H.; Ma, W.-Y.; Yang, T.-N.; Lan, S.-M. An investigation of the mechanisms of light-induced nickel plating on P-type silicon substrates. Int. J. Electrochem. Sci 2012, 7 , 10711-10721.

15. Minsek, D. Light Induced Electroless Plating. US Patent US20110052835 A1. 28 August 2009.

16. Mette, A.; Schetter, C.; Wissen, D.; Lust, S.; Glunz, S.; Willeke, G. Increasing the Efficiency of Screen-Printed Silicon Solar Cells by Light-Induced Silver Plating. In Proceedings of the Conference Record of the 4th World Conference on Photovoltaic Energy Conversion, Waikoloa, HI, USA, 7-12 May 2006. 
17. Hörteis, M.; Glunz, S.W. Fine line printed silicon solar cells exceeding $20 \%$ efficiency. Prog. Photovolt Res. Appl. 2008, 16, 555-560.

18. Lennon, A.; Yao, Y.; Wenham, S. Evolution of metal plating for silicon solar cell metallisation. Prog. Photovolt. Res. Appl. 2012, 21, 1454-1468.

19. Hilali, M.M.; Rohatgi, A.; To, B. Review and Understanding of Screen-Printed Contacts and Selective-Emitter Formation. In Proceedings of the 14th Workshop on Crystalline Silicon Solar Cells and Modules, 8-14 August 2004.

20. Neuhaus, D.-H.; Münzer, A. Industrial silicon wafer solar cells. Adv. OptoElectron. 2007, 2007, doi:10.1155/2007/24521.

21. Hannebauer, H.; Falcon, T.; Hesse, R.; Dullweber, T.; Brendel, R. 18.9\%-Efficient Screen-Printed Solar Cells Applying a Print-on-Print Process. In Proceedings of the 26th European Photovoltaic Solar Energy Conference, Hamburg, Germany, 5-9 September 2011.

22. Galiazzo, M.; Furin, V.; Tonini, D.; Cellere, G.; Baccini, A. Double Printing of Front Contact Ag in C-Si Solar Cells. In Proceedings of the 25th European Photovoltaic Solar Energy Conference, Valencia, Spain, 6-10 September 2010.

23. Ju, M.; Lee, Y.-J.; Lee, J.; Kim, B.; Ryu, K.; Choi, K.; Song, K.; Lee, K.; Han, C.; Jo, Y. Double screen printed metallization of crystalline silicon solar cells as low as $30 \mu \mathrm{m}$ metal line width for mass production. Solar Energy Mater. Solar Cells 2012, 100, 204-208.

24. Kamp, M.; Bartsch, J.; Nold, S.; Retzlaff, M.; Hörteis, M.; Glunz, S. Economic evaluation of two-step metallization processes for silicon solar cells. Energy Procedia 2011, 8, 558-564.

25. Solar Module Price Index. Available online: http://www.pvxchange.com/priceindex/Default.aspx? template_id=1\&langTag=en-GB (accessed on 15 August 2013),

26. Wenham, S. Buried-contact silicon solar cells. Prog. Photovolt Res. Appl. 1993, 1, 3-10.

27. Kerschaver, E.V.; Beaucarne, G. Back-contact solar cells: A review. Prog. Photovolt Res. Appl. 2006, 14, 107-123.

28. Green, M.A.; Emery, K.; Hishikawa, Y.; Warta, W.; Dunlop, E.D. Solar cell efficiency tables (version 39). Prog. Photovolt Res. Appl. 2011, 20, 12-20.

29. Tous, L.; Recaman Payo, M.; Ngamo, M.; Hernandez, J.L.; Poortmans, J.; Mertens, R.P. Evaluating Contact Resistance Using Epitaxially Grown Phosphorous Emitters. In Proceedings of the 26th European Photovoltaic Solar Energy Conference, Hamburg, Germany, 5-9 September 2011.

30. Weber, E.R. Transition metals in silicon. Appl. Phys. A 1983, 30, 1-22.

31. London Metal Exchange Home Page. Available online: http://www.lme.com/ (accessed on 21 October 2013).

32. The London Bullion Market Association (LBMA). Available online: http://www.lbma.org.uk/ pages/index.cfm?page_id=1 (accessed on 21 October 2013).

33. Milnes, A.G. Deep Impurities in Semiconductors; Wiley: New York, NY, USA. 1973.

34. Abd El Rehim, S.; Sayyah, S.; El Deeb, M. Electroplating of copper films on steel substrates from acidic gluconate baths. Appl. Surf. Sci. 2000, 165, 249-254.

35. Schroder, D.K.; Meier, D.L. Solar cell contact resistance-A review. Electron Devices IEEE Trans. 1984, 31, 637-647. 
36. Glunz, S.; Aleman, M.; Bartsch, J.; Bay, N.; Bayer, K.; Bergander, R.; Filipovic, A.; Greil, S.; Grohe, A.; Horteis, M. Progress in Advanced Metallization Technology at Fraunhofer ISE. In Proceedings of the 33rd IEEE Photovoltaic Specialists Conference, PVSC'08, San Diego, CA, USA, 11-16 May 2008.

37. Aleman, M.; Bay, N.; Barucha, D.; Knorz, A.; Biro, D.; Preu, R.; Glunz, S.; Assmus, M.; Jack, S.; Koehl, M. Advances in Electroless Nickel Plating for the Metallization of Silicon Solar Cells Using Different Structuring Techniques for the ARC. In Proceedings of the 24th European Photovoltaic Solar Energy Conference, Hamburg, Germany, 21-25 September 2009.

38. Bay, N.; Radthe, V.; Almán, M.; Bartsch, J.; Glunz, S. Electrolytic Nickel Deposition for the Front Side Metallization of Silicon Solar Cells. In Proceedings of the 24th European Photovoltaic Solar Energy Conference, Hamburg, Germany, 21-25 September 2009.

39. Aleman, M.; Bay, N.; Fabritius, M.; Glunz, S. Characterization of Electroless Nickel Plating on Silicon Solar Cells for the Front Side Metallization. In Proceedings of the 22nd European Photovoltaic Solar Energy Conference, Milan, Italy, 3-7 September 2007.

40. Rudolph, D.; Alemán, M.; Bay, N.; Mayer, K.; Glunz, S. Laser-Induced Nickel Deposition from an Aqueous Electrolyte for the Front-Side Metallization of Silicon Solar Cells. In Proceeding of the 23rd European Photovoltaic Solar Energy Conference, Valencia, Spain, 1-5 September 2008.

41. Schlesinger, M. Electroless deposition of nickel. Mod. Electroplat. 2000, 4, 667-684.

42. Bartsch, J.; Mondon, A.; Godejohann, B.; Hörteis, M.; Glunz, S. Advanced Front Side Metallization for Crystalline Silicon Solar Cells Based on a Fully Plated Contact. In Proceedings of the 25th European PV Solar Energy Conference and Exhibition, Valencia, Spain, 6-10 September 2010.

43. Kordás, K.; Leppävuori, S.; Békési, J.; Nánai, L.; Remes, J.; Vajtai, R.; Szatmári, S. Nickel deposition on porous silicon utilizing lasers. Appl. Surf. Sci. 2002, 186, 232-236.

44. Sasano, J.; Schmuki, P.; Sakka, T.; Ogata, Y.H. Laser-assisted nickel deposition onto porous silicon. Phys. Status Solidi A Appl. Res. 2003, 197, 46-50.

45. Wang, J.; Fei, X.; Yu, Z.; Zhao, G. Laser-induced selective deposition of Ni-P alloy on silicon. Appl. Surf. Sci. 1995, 84, 383-389.

46. Wehkamp, N.; Fell, A.; Bartsch, J.; Granek, F. Laser chemical metal deposition for silicon solar cell metallization. Energy Procedia 2012, 21, 47-57.

47. Röder, T.; Hoffmann, E.; Konrad, B.; Köhler, J. Low temperature laser metallization for silicon solar cells. Energy Procedia 2011, 8, 552-557.

48. Lee, E.K.; Lim, D.C.; Lee, K.H.; Lim, J.-H. Self-aligned Ni-P ohmic contact scheme for silicon solar cells by electroless deposition. Electron. Mater. Lett. 2012, 8, 391-395.

49. Mondon, A.; Bartsch, J.; Godejohann, B.-J.; Hörteis, M.; Glunz, S. Advanced Front Side Metallization for Crystalline Silicon Solar Cells Based on a Nickel-Silicon Contact. In Proceedings of the 2nd Workshop on Metallization for Crystalline Silicon Solar Cells-Status Trends and New Directions, Constance, Germany 13-15 April 2010.

50. Oh, W.-J.; Lee, S.-H. Investigation of selective emitter in single step diffusion process for plated $\mathrm{Ni} / \mathrm{Cu}$ metallization crystalline silicon solar cells. Curr. Appl. Phys. 2013, 13, S186-S189 
51. Ortega, P.; López, G.; Orpella, A.; Martin, I.; Colina, M.; Voz, C.; Bermejo, S.; Puigdollers, J.; Garcia, M.; Alcubilla, R. Crystalline Silicon Solar Cells beyond 20\% Efficiency. In Proceedings of the IEEE: Spanish Conference on Electron Devices (CDE), Palma de Mallorca, Spain, 8-11 February 2011.

52. Tous, L.; Russell, R.; Das, J.; Labie, R.; Ngamo, M.; Horzel, J.; Philipsen, H.; Sniekers, J.; Vandermissen, K.; Van Den Brekel, L. Large area copper plated silicon solar cell exceeding 19.5\% efficiency. Energy Procedia 2012, 21, 58-65.

53. Hu, G.; Wu, H.; Yang, F. Direct electroless nickel plating on silicon surface. Chin. Sci. Bull. 2004, 49, 2363-2367.

54. Lee, J.D.; Kwon, H.Y.; Lee, S.H. Analysis of front metal contact for plated Ni/Cu silicon solar cell. Electron. Mater. Lett. 2011, 7, 349-352.

55. Min, S.K.; Kim, D.H.; Lee, S.H. Nickel silicide for $\mathrm{Ni} / \mathrm{Cu}$ contact mono-silicon solar cells. Electron. Mater. Lett. 2013, 9, 433-435.

56. Nguyen, A.; Rane-Fondacaro, M.; Efstathiadis, H.; Haldar, P.; Michaelson, L.; Wang, C.; Munoz, K.; Tyson, T.; Gallegos, A. Formation of a Low Ohmic Contact Nickel Silicide Layer on Textured Silicon Wafers Using Electroless Nickel Plating. In Proceedings of the 25th European Photovoltaic Solar Energy Conference, Valencia, Spain, 6-10 September 2010.

57. Book, F.; Raabe, B.; Hahn, G. Two Diffusion Step Selective Emitter: Comparison of Mask Opening by Laser or Etching Paste. In Proceedings of the 23rd European Photovoltaic Solar Energy Conference, Valencia, Spain, 1-5 September 2008.

58. Neckermann, K.; Correia, S.; Andra, G. Local Structuring of Dielectric Layers on Silicon for Improved Solar Cell Metallization. In Proceedings of the 22nd European Photovoltaic Solar Energy Conference, Milan, Italy 3-7 September 2007.

59. Bähr, M.; Kim, S.; Sridharan, S.; Khadilkar, C.; Shaikh, A.; Köhler, I.; Reichardt, M.; Kumar, M. A New Approach for the Front Side Metallization of Industrial Type Silicon Solar Cells Using a Structurization by Etching. In Proceedings of the 22nd European Photovoltaic Solar Energy Conference, Milan, Italy, 3-7 September 2007.

60. Röder, T.; Hoffmann, E.; Köhler, J.; Werner, J. $30 \mu \mathrm{m}$ Wide Contacts on Silicon Cells by Laser Transfer. In Proceedings of the 35th IEEE Photovoltaic Specialists Conference (PVSC), Honolulu, HI, USA, 20-25 June 2010.

61. Lennon, A.; Renn, M.; King, B.; Wenham, S. Aerosol Jet Etching for Silicon Solar Cells. In Proceedings of 24th European Photovoltaic Solar Energy Conference, Hamburg, Germany, 21-25 September 2009.

62. Mette, A.; Richter, P.; Hörteis, M.; Glunz, S. Metal aerosol jet printing for solar cell metallization. Prog. Photovolt Res. Appl. 2007, 15, 621-627.

63. Bruton, T.; Mason, N.; Roberts, S.; Hartley, O.N.; Gledhill, S.; Fernandez, J.; Russell, R.; Warta, W.; Glunz, S.; Schultz, O. Towards 20\% Efficient Silicon Solar Cells Manufactured at 60 MWp per Annum. In Proceedings of 3rd World Conference on Photovoltaic Energy Conversion, Osaka, Japan, 18 May 2003. 
64. Bartsch, J.; Mondon, A.; Schetter, C.; Hörteis, M.; Glunz, S. Copper as Conducting Layer in Advanced Front Side Metallization Processes for Crystalline Silicon Solar Cells, Exceeding 20\% on Printed Seed Layers. In Proceedings of 35th IEEE: Photovoltaic Specialists Conference (PVSC), Honolulu, HI, USA, 20-25 June 2010.

65. You, J.; Kang, J.; Kim, D.; Jungho Pak, J.; Sik Kang, C. Copper metallization for crystalline Si solar cells. Solar Energy Mater. Solar Cells 2003, 79, 339-345.

66. Tous, L.; Lerat, J.F.; Emeraud, T.; Negru, R.; Huet, K.; Uruena, A.; Aleman, M.; Meersschaut, J.; Bender, H.; Russell, R. Nickel silicide contacts formed by excimer laser annealing for high efficiency solar cells. Prog. Photovolt Res. Appl. 2013, 21, 257-275

67. Cho, K.-Y.; Kim, J.; Lee, E.-J.; Hong, K.-K.; Lee, H.-W.; Shim, J.-M.; Oh, D.-J.; Shin, J.-E.; Kim, J.-S.; Seo, J.-K. Shinsung Solar Energy High Efficiency Commercial Crystalline Si Solar Cells. In Proceedings of 38th IEEE: Photovoltaic Specialists Conference (PVSC), Austin Texas, TX, USA, 3-8 June 2012.

68. You, J.; Kang, J.; Kim, D.; Pak, J.J.; Kang, C.S. A Study on Cu Metallization for Crystalline Si Solar Cells. In Proceedings of the Conference Record of the Twenty-Ninth IEEE, Photovoltaic Specialists Conference, New Orleans, TX, USA, 20-24 May 2002.

69. Michaelson, L.; Munoz, K.; Wang, J.C.; Xi, Y.; Tyson, T.; Gallegos, A. Improved Contact Formation for Large Area Solar Cells Using the Alternative Seed Layer (ASL) Process. In Proceedings of the IEEE: 38th Photovoltaic Specialists Conference (PVSC), Frankfurt, Germany, 24-28 September 2012.

70. Bartsch, J.; Mondon, A.; Kamp, M.; Kraft, A.; Wendling, M.; Mehling, M.; Wehkamp, N.; Jawaid, M.; Lorenz, A.; Clement, F. Copper as Conducting Layer in the Front Side Metallization of Crystalline Silicon Solar Cells-Challenges, Processes and Characterization. In Proceedings of the 2nd Workshop on Metallization for Crystalline Silicon Solar Cells-Status, Trends and New Directions, Constance, Germany, Konstanz, Germany, 15 April 2010.

71. SCHOTT Solar and SCHMID Group Lift PERC Efficiency Records to Values of up to $21 \%$. Schmid Press Release. Available online: http://www.schmid-group.com/en/press-cornernews/press-releases/p107/schott-solar-and-schmid-lift-perc-efficieny-to-up-to-21.html (accessed on 30 October 2013).

72. Imec and Meco Present High Efficiency and Cost-Effective Copper Technology for i-PERC-Type Silicon Solar Cells. IMEC Press Release. Available online: http://www2.imec.be/be_en/press/ imec-news/imecmeco.html (accessed on 20 October 2013).

73. Russell, R.; Tous, L.; Labie, R.; Aleman, M.; Duerinckx, F.; Bertens, J.; Horiuchi,T.; Szlufcik, J. Cost-effective and reliable $\mathrm{Ni} / \mathrm{Cu}$ plating for $\mathrm{p}$ - and n-type PERx silicon solar cells yielding efficiencies above 20.5\%. Photovolt. Int. 2013, 2013, 62-69.

74. Dohyeon, K.; Sung-Hoon, C.; Jong-Keun, L.; Kyumin, L.; Myung-Ick, H.; Won-jae, L.; Eun, C.C. Approaching 20\%-Efficient Selective-Emitter Solar Cells with Copper Front Contacts on Industrial $156 \mathrm{~mm} \mathrm{Cz} \mathrm{Si} \mathrm{Wafers.} \mathrm{In} \mathrm{Proceedings} \mathrm{of} \mathrm{27th} \mathrm{European} \mathrm{Photovoltaic} \mathrm{Solar} \mathrm{Energy} \mathrm{Conference} \mathrm{and}$ Exhibition, Frankfurt, Germany, 24-28 September 2012.

75. Hallam, B.; Wenham, S.; Sugianto, A.; Mai, L.; Chong, C.; Edwards, M.; Jordan, D.; Fath, P. Record large-area p-type $\mathrm{Cz}$ production cell efficiency of $19.3 \%$ based on LDSE technology. IEEE J. Photovoltaic. 2011, 1, 43-48. 
76. Kyeong-Yeon, C.; Jisso, K.; Ji-Sun, K.; Ji-Hyun, K.; Soo-Jeong, C.; Soo-Hong, L.; Hae-Seok, L.; Eun-Joo, L. Shinsung Solar Energy over 19\% Commercial Selective Emitter Solar Cells with $\mathrm{Ni} / \mathrm{Cu}$ Plated Contact. In Proceedings of the 27th European Photovoltaic Solar Energy Conference and Exhibition, Frankfurt, Germany, 24-28 September 2012.

77. Lee, E.; Lee, H.; Choi, J.; Oh, D.; Shim, J.; Cho, K.; Kim, J.; Lee, S.; Hallam, B.; Wenham, S.R. Improved LDSE processing for the avoidance of overplating yielding 19.2\% efficiency on commercial grade crystalline Si solar cell. Solar Energy Mater. Solar Cells 2011, 95, 3592-3595.

78. Suntech White Paper. Available online: http://am.suntech-power.com/images/stories/pdf/ other/whitepaper_final_081511.pdf (accessed on 30th October 2013).

79. Hernández, J.L.; Adachi, D; Yoshikawa, K.; Schroos, D.; Van Assche, E.; Feltrin, A.; Valckx, N.; Menou, N.; Poortmans, J.; Yoshimi, M.; et al. High Efficiency Copper Electroplated Heterojunction Solar Cells. In Proceedings of the 27th European Photovoltaic Solar Energy Conference and Exhibition, Frankfurt, Germany, 24-28 September 2012.

80. Papet, P.; Hermans, J.; Söderström, T.; Cucinelli, M.; Andreetta, L.; Bätzner, D.; Frammelsberger, W.; Lachenal, D.; Meixenberger, J.; Legradic, B.; et al. Heterojunction Solar Cells with Electroplated Ni/Cu Front Electrode. In Proceedings of the 28th European Photovoltaic Solar Energy Conference and Exhibition, Paris, France, 30 September-4 October 2013.

81. Metz, A.; Adler, D.; Bagus, S.; Blanke, H.; Bothar, M.; Brouwer, E.; Dauwe, S.; Dressler, K.; Droessler, R.; Droste, T. Industrial high performance crystalline silicon solar cells and modules based on rear surface passivation technology. Solar Energy Mater. Solar Cells 2014, 120, $417-425$.

82. Aleman, M.; Tous, L.; Cornagliotti, E.; Duerinckx, F.; John, J.; Posthuma, N.; Russell, R.; Singh, S.; Sleeckx, E.; Uruena de Castro, A.; et al. Large-Area High-Efficiency n-Type Si Rear Junction Cells Featuring Laser Ablation and Cu-Plated Front Contacts. In Proceedings of the 28th European Photovoltaic Solar Energy Conference and Exhibition, Paris, France, 30 September-4 October 2013.

83. Tous, L.; van Dorp, D.; Russell, R.; Das, J.; Aleman, M.; Bender, H.; Meersschaut, J.; Opsomer, K.; Poortmans, J.; Mertens, R. Electroless nickel deposition and silicide formation for advanced front side metallization of industrial silicon solar cells. Energy Procedia 2012, 21, $39-46$.

84. Kim, D.H.; Lee, S.H. Investigation on plated Ni/Cu contact for mono-crystalline silicon solar cells. Electron. Mater. Lett. 2013, 9, 677-681.

85. Mondon, A.; Jawaid, M.; Bartsch, J.; Glatthaar, M.; Glunz, S. Microstructure analysis of the interface situation and adhesion of thermally formed nickel silicide for plated nickel-copper contacts on silicon solar cells. Solar Energy Mater. Solar Cells 2013, 117, 209-213.

86. Seren, S.; Braun, S.; Schiele, Y.; Hahn, G.; Terheiden, B. Nickel Plating on P+ Silicon: A Characterization of Contact Resistivity and Line Resistance. In Proceedings of the 27th European Photovoltaic Solar Energy Conference and Exhibition, Frankfurt, Germany, 24-28 September 2012.

87. Bay, N.; Burschik, J.; Cimiotti, G.; Fritz, N.; Kösterke, N.; Kray, D.; Lösel, A.; Lühn, O.; Sieber, M.; Träger, A. Adhesive One Step Ni/Ag and Ni/Cu/Ag Inline Direct Plating on Laser Processed Selective Emitter Structures. In Proceedings of the 25th European Photovoltaic Solar Energy Conference and Exhibition, Valincia, Spain, 6-10 September 2010. 
88. Jacquet, P.A. Adhesion of electrolytic copper deposits. Trans. Electrochem. Soc. 1934, 66, 393-426.

89. Walker, G.H.; Lewis, B.W. A study of the adhesion of copper to nickel. Metall. Mater. Trans. B 1971, 2, 2189-2193.

90. Kray, D.; Bay, N.; Cimiotti, G.; Kleinschmidt, S.; Kösterke, N.; Losel, A.; Sailer, M.; Trager, A.; Kuhnlein, H.; Nussbaumer, H. Industrial LCP Selective Emitter Solar Cells With Plated Contacts. In Proceedings of IEEE; 35th Photovoltaic Specialists Conference (PVSC), Honolulu, HI, USA, 20-25 June 2010.

91. Braun, S.; Zuschlag, A.; Raabe, B.; Hahn, G. The origin of background plating. Energy Procedia 2011, 8, 565-570.

92. Saint-Cast, P.; Tanay, F.; Alemán, M.; Reichel, C.; Bartsch, J.; Hofmann, M.; Rentsch, J.; Preu, R. Relevant Pinhole Characterisation Methods For Dielectric Layers For Silicon Solar Cells. In Proceedings of the 24th European Photovoltaic Solar Energy Conference and Exhibition, Hamburg, Germany, 21-25 September 2009.

93. Russell, R.; Tous, L.; Philipsen, H.; Horzel, J.; Cornagliotti, E.; Ngamo, M.; Choulat, P.; Labie, R.; Beckers, J.; Bertens, J.; et al. A Simple Copper Metallisation Process for High Cell Efficiencies and Reliable Modules. In Proceedings of the 27th European Photovoltaic Solar Energy Conference, Frankfurt, Germany, 24-28 September 2012.

(C) 2014 by the authors; licensee MDPI, Basel, Switzerland. This article is an open access article distributed under the terms and conditions of the Creative Commons Attribution license (http://creativecommons.org/licenses/by/3.0/). 